\title{
DEVLET ANA'DA DİN
}

\section{$\ddot{\mathbf{O} z}$}

Kemal Tahir Türk edebiyatının en önemli yazarlarından biridir ve Devlet Ana onun en bilinen romanıdır. İlgi alanına toplumun inşası giren Kemal Tahir bazı sorunların çözümünde tarihten yararlanılması gerektiğini savunmuştur. Din de toplumun önemli parçalarından biridir. Bu çalışmanın amacı Kemal Tahir'in Osmanlı Devleti'nin kuruluş dönemini anlatan Devlet Ana romanında dine yaklaşımını anlamaktır. Bu bağlamda Devlet Ana romanı "din bağlamında yaşanan ikilikler", "toplumsal çürüme, din ve din adamları", "yeni Müslümanların benimsenme(me)si ve gayri Müslimlere bakış" başlıkları altında ele alınmıştır.

Devlet Ana'da İslam öncesi ve İslami kimi inanç kalıpları bireylerin günlük yaşamlarında bir arada yer almaktadır. Bunun yanında yeni Müslümanların eski dinlerine ait davranış kalıplarını kullandıkları görülmüştür. Aynı zamanda bazı Müslümanların farklı kültürlerin etkiyle şarap içmek gibi kimi İslam dışı davranışları gerçekleştirdikleri fark edilmiştir. Kemal Tahir Devlet Ana romanında toplumsal çürümeyi din adamları sınıfı etrafında somutlaştırmıştır. Din adamları sınıfından kişiler paraya düşkünlükleri ile romanda ön plana çıkarılmıştır. Bazı Müslümanların Hristiyanları ve yeni Müslüman olmuşları kabullenmekte yaşadıkları zorluklar da romanda tespit edilmiştir.

Anahtar Sözcükler: Kemal Tahir, din, Osmanlı Devleti.

\section{RELIGION IN DEVLET ANA}

\begin{abstract}
Kemal Tahir is one of the most important writers in Turkish literature and "Devlet Ana" is his well-known novel. Kemal Tahir was interested in the discussions about the construction of society and he defended that we should benefit from history in order to solve our problems. The religion is one of the most important parts of the society, too. The purpose of this work is to understand the way Kemal Tahir approached the religion in "Devlet Ana" in which the establishment period of the Ottoman Empire was described. This novel was examined under the titles of "religiously experienced dualities" "social decay, the religion and the clergy", "the acceptance problems of the new Muslims, the perspective to the non-Muslims".

In "Devlet Ana", Pre-Islamic and Islamic belief patterns found a place in the daily life of the individuals. In addition, it was seen that the new Muslims used some behavior patterns of the old religion, Christianity, while living the new religion. At the same time, some Muslim characters of the novel performed in non-Islamic behavior like drinking wine under the influence of different cultures. It was seen that Kemal Tahir embodied the social
\end{abstract}

\footnotetext{
*Dr.; Millî Eğitim Bakanlığı, zekasemih@hotmail.com.
} 
corruption around the clergy in "Devlet Ana". It is clear that the clergy were brought to the forefront with their vulnerability to the property. It was expressed that some Muslims had difficulty in accepting Christians and even new Muslims in the novel.

Keywords: Kemal Tahir, religion, The Ottoman Empire.

\section{Giriş}

Popüler roman türünün alt sınıflarından olan tarihsel roman, toplumu oluşturan insanların ortak mazisine hitap eden özelliğe sahiptir. Bu türün merkezinde tarihsel bir olay yer alır. Batı edebiyatında Walter Scott ile başlatılan tarihsel romanlarla, İngiliz, Fransız ve Alman yazarlar, gelecek inşa etme kaygısı içinde geçmişin değerlerinden yararlanmaya yönelmiştir. Ulus devletlerin kurulması nedeniyle örnek tip ve kahramanlar arayan sanatçılar tarihe döndürmüşlerdir yüzlerini (Kolcu, 2013:105).

Jeremi Hawthorn tarihsel romanı belirlenmiş bir tarihî çevre içinde karakter ve olayların işlendiği roman türü olarak değerlendirir. Ona göre tarihsel romanları diğer tür romanlardan ayıran özellikleri, seçilmiş bir mekânın görünüşü, kurumlar, binalar ve karakterlerin tavırları belirler. Aynı zamanda bu tür romanlar tarihsel gerçeklerin özünü verme gayreti içindedirler (Yalçın,1992:175). Türk edebiyatında Ahmet Mithat Efendi'nin "Yeniçeriler"i ve Namık Kemal'in "Cezmi"si ile başlayan tarihsel roman geleneği topluma tarih bilincinin verilmesi adına önemli bir işlevi yerine getirir. Türk edebiyatında tarihsel romanın tezli ve sanatsal bir dönüşüme uğraması Kemal Tahir, Tarık Buğra, Nihal Atsız, Mustafa Necati Sepetçioğlu gibi isimlerin katkısıyla gerçekleşir. Türk tarihsel romanları genel olarak İslamiyet öncesi Türk tarihini, Türk-İslam tarihini, Osmanlı tarihini, Kurtuluş Savaşı dönemini ele almaktadır (Kolcu, 2013: 105-106).

Cumhuriyet Dönemi'nde eserler veren ve Türk tarihsel roman geleneğinin içinde yer alan yazarlardan Kemal Tahir'in roman sahasındaki eserleri üç ana başlık altında ele alınabilir: Köy ve kasaba romanları, şehir romanları ve tarihsel romanlar (Kudret, 19901: 154). Aynı zamanda Kemal Tahir dünya görüşlerini üç ana başlık altında toplar. Bunlar Hristiyanlık (dinsel) dünya görüşü, Freudçu (bireysel) dünya görüşü ve Marksçı (bilimsel-sosyalist) dünya görüşü. $\mathrm{O}$, diğer bütün dünya görüşlerinin son kertede bu üç başl1ktan birine indirgenebileceği kanaatindedir. Kemal Tahir, tutarlı ve doğru fikirlere ulaşmanın sistemli düşünme ile gerçekleşeceğini ifade eder. Sistemli düşünmenin ise bir dünya görüşüne sahip olmakla mümkün olduğunun altını çizer. Kemal Tahir, yukarıda adı geçen dünya görüşlerinden bilimsel sosyalizmi benimsemiştir (Yavuz, 2000: 160).

Diyalektik maddecilik, Marksizmin düşünce sistemini yansıtır. Kemal Tahir de Marks ve Engels'in çerçevesini belirlediği diyalektik materyalizmin taraftarıdır. Doğada ve tarihte 
süreçlerin, kendi içlerinden doğan karşıtlıklar vasıtasıyla gerçekleştiğini ve karşılaşılan her türden olayın bu türden maddi ilişkilerle açıklanmasını öngören diyalektik maddecilik duyularla algılanan maddi dünyanın zihin ve ruhtan bağımsız bir şekilde incelenmesini ileri sürer. Toplumların tarih içinde yaşadığı gelişmeleri ve değişmeleri inceleyen tarihsel maddecilik anlayışı da dayanağını Marksizm'in yukarıda ifade edilen diyalektik materyalizminden alır (Yavuz, 2000: 162).

Tarih ve toplumu anlamada tarihsel maddeciliği benimseyen Kemal Tahir, Osmanlı'dan Cumhuriyet'e Türk toplumunu bu bakış açısıyla ele almıştır. Marksizme göre bütün toplumların yapısını belirleyen ana unsur ekonomidir. Toplumsal ilişkilerin temelinde de maddi üretim ilişsisi yatmaktadır. Bu nedenledir ki bir toplumun yapısını anlamanın yolu onun üretim ilişkilerini anlamaktan geçer. Kemal Tahir'e göre toplumu geleceğe taşımak için onun bugününü anlamak bugününü anlamak için de geçmişini doğru kavramak gerekir (Yavuz, 2000: 162-163).

Toplumun gerçeklerini kavrayabilmek için Kemal Tahir, toplumun tarihini bilmenin zorunlu olduğunu ifade eder. İnsan ve toplumun özgürleşmesinde gerçekçiliği zorunlu gören Kemal Tahir, bireyin özgürleşmesi için kendini kuşatan zorunlulukların ne olduğunu kavraması gerektiğini vurgular. Ona göre gerçekçilik bu zorunlulukları kavramanın tek yoludur. Bunun ardından ise özgürlük gelmektedir. Dünyayı, kendini kuşatan zorunlulukları kavrayan birey, onları kendi istekleri doğrultusunda değiştirdiği takdirde özgürlüğe ulaşacaktır (Yavur, 2000: 169-170). Kemal Tahir'in sanatı ele alış şekli de Pospelov'un ifadeleri doğrultusundadır: "Her hakiki sanat yaratışı gibi toplumcu gerçekçi sanat da, yaşamı yalnızca yansıtıp açıklamakla kalmaz, yaşamın değiştirilmesine de sanatın kendine özgü tarzları içinde katkı sağlar" (Pospelov, 2005: 489).

Kemal Tahir, gerçekçi olma yolunda iki engelin varlığından söz eder. Bunlardan birincisi tembellikten, ideolojik koşullanmalardan ya da yanlış bilgilenmeden doğan bilgisizliktir. İkinci engel ise bireyin aklını gerçeklere göre değil de gerçekleri aklına göre kullanma gayretidir. Bu yolla birey, gerçekleri önceden benimsediği şekilde görür. Bireyin gönlünden geçen istekleri doğrulayan küçük olaylar, büyütülür ve genelleştirilir. Bunun sonucunda birey gerçekle alakası olmayan metafizik bir dünya kurmuş olur kendine. Bunun için Kemal Tahir, bireye içinde yaşadığı gerçekliğin ne olduğunu anlatmanın ve onu gerçekliğe çekmenin gerekliliğinin de altını çizer. Bu bağlamda Kemal Tahir'in romanı Türk toplumuna içinde yaşadığ gerçekliği göstermek ve onun üzerinde düşünmesini sağlamak yolunda bir arayıştır (Yavuz, 2000: 171-172). 
Sosyal kurumların, toplumların tarihsel süreç içinde elde ettikleri kimliklerine bağl1 olarak oluştuğunu düşünen Kemal Tahir, dinî toplumun dışında var olan bir kurum olarak değil de toplum tarafından şekillenen ve aynı zamanda toplumu da şekillendiren bir üst yapı olarak değerlendirir. Toplumsal gerçeklik olarak değerlendirdiği dinin, eski zamanlardaki önemini yitirdiği kanaatindedir. Osmanlı Devleti'nin dine dayalı bir devlet yapılanması içinde olmadığını düşünen Kemal Tahir, buna kanıt olarak da şeyhülislamın canının padişahın iki dudağı arasında olmasını ileri sürer (Coşkun, 2006: 338-339). Sezai Coşkun, onun Fermanlı Hoca adlı hikâyesinden hareketle şu genellemede bulunur:

Yazarın dine ve din adamlarına bakışını 'Fermanlı Hoca' isimli hikâyesi özetler.

Hikâyede, kurnaz, yalanc1, dinî kaidelere kendi çıarlarına uyduğu müddetçe riayet eden bir din adamı tipiyle karşılaşılır. Fermanlı Hoca'nın temsil ettiği bu tip ve bu tiple alakalı yazarın bakışı, yazarın hayatının hiçbir evresinde değişmez (Coşkun, 2006: 339).

Kemal Tahir'in Marksist tarihsel maddeci diyalektiğe dayanan düşüncesine göre din ve töreler köy halkının geriliğinin en önemli sebebidir. Onun bu bakış açısını Ahmet Kabaklı şu şekilde ifade eder:

(...) Türk köyünü ayakta tutan töreleri fena halde hırpalayarak, din adamlarının çoğunu iftira ölçüsünde kara, gerici, çıkarcı ve ahlâksız gibi tasvir ederek onun da zaman zaman tarafsız bir romancı olmaktan uzaklaştığı görülmektedir. Geniş kültürüne rağmen gerekli olan geniş bakışı doktrin yüzünden bulamamaktadır (Kabakl1, 2004: 297).

Pospelov, toplumcu gerçekçi roman anlayışı içinde yeni toplum sisteminin olumlanışının yanında eski düzenden arta kalmış ve insanların mutlu geleceklerini kurmalarına engel olan şeylerin, yadsınması ve eleştirisinin altını çizer ( Pospelov, 2005: 506). Bunun içindir ki bir parçası olduğu toplumun milli değerlerinden yararlanan Kemal Tahir, Devlet Ana adlı romanında Türkleri, Bizans tekfurlarının yönetimi altında ezilen Hıristiyan halkın kurtarıcısı, Osman Bey ve adamlarını insanlar arasında din ayrımı yapmayan, farklı dinden insanlara zulmetmeyen insanlar (Gündüz, 2011: 464) olarak gösterirken güçlerini dinden alan kişileri olumsuz yönleri ile sergilemektedir. Böylece kendi dünya görüşü çerçevesinde toplumun "mutlu geleceğinin kurulmasında "engel olarak gördüğü ve çıkarlarını din üzerinden elde eden insanları eleştirmektedir.

\section{Din Bağlamında Yaşanan İkilikler}

Devlet Ana romanında İslamiyet öncesi ve İslami inanç sistemleri bir arada yer almaktadır. Bu bağlamda Tanrı'nın ifade edilişşsekli dikkate değerdir. Hophop Kadı, Selçuk 
sultanının Eskişehir sancak beyi ve Şeyh Edebali'nin kızı Balkız ile evlenmek isteyen Alışar'ın kadısıdır. Hophop Kadı, Moğol eşkıyası Çudaroğlu'ndan Şeyh Edebali'nin kızını altın karşılığında kaçırmasını ister. Çudaroğlu, Kıbrıs manastırında Sen-Jan şövalyeleri arasında bulunmuş, Ertuğrul Gazi ve boyunu yok edip Bitinya Prensliği’ne egemen olmayı planlayan, Bacıbey'in oğlu Demircan'ı öldüren Notüs Gladyüs ve Türkopol'ü de bu işe dâhil eder; çünkü Şeyh Edebali’den korkmaktadır. Bunu ifade ederken kullandığı "ak Tanrı”, "soluk renkli Tanrı” ifadeleri ile gök ve dağ 1 kendisine şahit göstermesi ilginçtir:

Biz tartımızı biliriz Beyim! Çizmeden yukarı çıkmayız! İmparatorun kızını iste, sürüyüp getirmezsem, ak Tanrı belâmı versin! (...) Akılsızla iş tutmayacaksın ki, zarar etmeyesin! Pişman olunacak işe ben yapışmam gerek ki, sen, "Geri dur" diyerek önleyesin! Bir işe hesapsız kitapsız saldıran kişiyi adam sayma! Çünkü sana zararı dokunur! Mavi görünen gök, dağ ve de soluk renkli Tanrı tanık (Tahir, 2004: 278-279).

Orta Asya inancında beyaz renk ikinci dereceden bir tanrı olan Ülgen'in rengi sayılmıştır. Ülgen'in Gök Tanrı'nın yerini alması ile de beyaz renk Türk inanç sisteminde önemini arttırmıştır. Yaratılış sırasında Ülgen'e ilham veren ruhun adı da Ak-ene'dir (ana). Bu bağlamda gök ve yere ait varlıklar arasında gök ile ilgili olanlar beyaz ile anılmıştır (Çoruhlu, 2011: 215-216). Abakan şamanlarından derlenen "Gök tanrıda gök bulut, ak tanrıda ak bulut. Ak tanrı, merhametli han! Eğri buluttan etekli, çatal bulut ayaklı, Çobanyıldızı Tanrı, Çobanyıldızı..." (Çoruhlu, 2011: 216) duasında bu özelliği görmek mümkündür. Dağ, Türklerin dinî yaşamlarında önemli bir yere sahiptir. Türklerin atalarının mağaranın bulunduğu Kögmen, Ulan Bator Yazıtı'nda diğer tanrıların arasında yer alan tanrıdır. Eski Türklerden kalan metinlerde kurban sunmak maksadıyla dağlara yapılan hac yolculuklarından söz edilmektedir. Orta Asya'daki söylencelerin birçoğunda da dağların arasından çıkış genel bir özellik arz etmektedir (Roux, 2011: 62).

Devlet Ana'da yer alan kahramanlar eski inanç sistemleri ile yeni dinî bilgilerini bir arada kullanmaktadırlar. Alışar Bey, Moğol Çudaroğlu'nu Şeyh Edebali’nin kızını kaçırmaya ikna etmek amacındadır. Çudaroğlu ise Notüs Gladyüs ve Türkopol'ü bu iş için kullanma niyetindedir; çünkü Şeyh Edebali'nin gücünden çekinmektedir. Çudaroğlu'nun düşüncelerini ifade ederken "at sürülerinin tanrısı kara kartal” a şükretmesi dikkat çekicidir.

(...) Bize geldi mi, biz işimizi biliriz. Alışar Efendim "Ol” desin, şuraya yatıp ölmezsem, Demirciler piri Davut Peygamber örsünde ezileyim! Ahi şeyhi kızını sürümeye geldi mi... Kışkırtma bize işlemez, at sürülerinin tanrısı kara kartala 
şükür. Ateş demekle ağız yanmaz ve de öküz ayağı olmaktan buzağı başı olma yeğdir (Tahir, 2004: 280).

Dünya ağacının tepesinde yer alan kartalın Yakutlarda en yüksek ruhları taşıdığına inanılmakta ve kartal, Gök Tanrı'yı ya da şaman ruhunu simgelemektedir. Göktürk ve Uygur Türklerinde koruyucu ruhun ve adaletin simgesi olarak kullanılan kartal aynı zamanda hükümdar ve beyleri de simgelemekteydi. Gök Tanrı'nın simgesi olarak kabul edilen kartala kurbanlar sunulduğu gibi o, olumsuz varlıklara karşı iyiyi temsil eden bir özelliğe de sahiptir (Çoruhlu, 2011: 156).

Roux, at ile gök arasında eski Türk dünyasında bir bağlantının varlığından söz eder. Milattan önceki dönemlerde Bozkır inancında atın gök kökenli olduğuna ya da göğe benzediğine dair inanç mevcuttur. On iki hayvanlı takvimde at, güneşin en yüksekte bulunduğu aya karşılık gelirken Kutadgu Bilig’te zamanın simgesi olarak kullanılmaktadır. Turfan metinlerinde ise at resimleri gögün rengi olan maviye boyanmışken Kaşgarlı Mahmut sözlüğünde uçan at simgesine yer vermiştir (Roux, 2011: 35).

Notüs Gladyüs, Balkız’ın kaçırılması için Alışar Bey'den beş yüz altın ister. Bunu Çudaroğlu, Alışar Bey’e şu şekilde ifade eder: “Keşiş dağ Şeytan ne demekte? Demekte ki, kör şeytan...” (Tahir, 2004: 282). Romanda dağın tanrısal özelliğinin altı çizilmektedir ki bu Orta Asya inanç sisteminin bir yansıması olarak değerlendirilebilir. Bu konuda Roux şu tespitte bulunur:

(...) Bütün Türk ve Moğol toplumlarınca kutsallaştırılmış, belli bir adla çağrılan, özel ve bilinen bir dağın her zaman var olduğu bir gerçektir; onun yanında ayinler vasıtasıyla, örneğin aşiretin hayvan ataları tarafından yaratılması, bir kurucu kahramana sağlamış olduğu güçlü destek ve nihayet özellikle bir göçten sonra yeni gelen bir kimseye, buna atıf yapılan meziyetlerin aktarılması dolayısıyla, değerlendirilen diğer dağlar mevcuttur (Roux, 1994: 125).

İslam öncesi ve İslami inanç kalıpları insanların yaşamında bir arada durmaya devam etmektedir. Bacıbey oğlunun katillerinin kim olduğunu öğrenmek için para karşılığında Türkler için casusluk yapan Moğol Kamagan Derviş’in mağarasına yanında Aslıhan, Kerim ve Mavro olduğu hâlde gider. Bacıbey, yanında aynı zamanda kurban edilecek bir horoz da götürmektedir. Horoz ya da tavuk Orta Asya Türk inanışında ayrı bir yere sahiptir. Bu konuda Çoruhlu şu tespitte bulunur:

Proto-Türk ya da Hun devrine ait Pazırık kurganlarından çıkarılan eserler arasında, deriden kesilmiş ya da lahitler üzerine oyulmuş ya da elbiselerde yer almış bir şekilde karşımıza çıkan horoz-tavuk figürleri büyük olasılıkla kötü ruhları kovan, 
koruyucu bir simgeydi. Özellikle horoz günün ağarışını haber vermesiyle bu anlamı ifade ediyordu (Çoruhlu, 2011: 171).

Mağara da eski Türk inanç sisteminde önemli bir yere sahiptir. "Gizli-kutsal âlemle bu yer dünyası arasında uzanan geçidi temsil ede(n)" (Beydili, 2005: 367) mağaralarda eski Türkler gökyüzüne ve tanrıya kurbanlarını sunarlardı. Eski Türk inancına göre kurt, Tanrı Dağları'ndaki bir mağaranın içinde on erkek yavru dünyaya getirmiştir ki bunlardan biri Göktürk Devleti'nin kurucusu olan Aşina'dır. Bunun yanında mağara Türk halk kültüründe şeytanların mekânı olarak değerlendirilen yerlerdir (Beydili, 2005: 367-368).

Kamagan Derviş şaman büyücüleri andırır şekilde davranmaya başlar. Esrime yaşayan Kamagan Derviş'in ifadeleri bu noktada ilginçtir:

Ey bilinmezlerin hanı! Ey gizlilerin beyi! Bu oyunu size kurduk, oynıya oynıya gel! Yolda gecikme! Beni utandırma! Saçlarını yolarım, yolarım, -Saçlarını yolar gibi yaptı-: Kanın dökerim dökerim! Allah hey! Tanrı hey! Çalap hey! Bir dileğim var sizlerden, bir dileğim var bunlardan, bir dileğim var şunlardan, bir dileğim var onlardan... İşin başı bismillah! Kur'an'ın başı bismillâh! Batağa gittim batağa... Yalnız batağa... derin batağa... İş̧te oyuna çıktım yüreksiz batak, hayın batak! Ey ulu ışık! Bir dileğim var senden, yırt karanlığı, sıyır, gizliliği göster bana... Acıyıcı adlı, acıyışından, verici adlı, vericiliğinden, bitirici adlı, bitiriciliğinden kanlılarımı isterim, bir dileğim budur sizlerden... Analar hakkına... Kardaşlar hakkına... Bir dileğim budur onlardan (Tahir, 2004: 294).

Esrimenin ileri safhalarında Kamagan Derviş'in Keşiş dağına yüklediği anlam da önemlidir:

(...) Ayakladım oooh, çiğnedim geçtim işte! Oh oh! Keşiş dağını tuttum, sevin Bacıbey, ayağım düze bastı. Bu kurbanım sana ulaşsın Keşiş dağı! Senden kopsun, Ülgen'in yoluna düşsün! Bir dileğim budur senden! Ey göklerin direği Keşiş dağı... Ey bize serin esintiler veren... (...) Yiğitlerimizin atası, gelinlerimizin kayınbabası yüce Keşiş dağı, bir dileğim budur senden... (...) (Tahir, 2004: 295-296).

Kamagan Derviş’in ifadeleri ile aşağıya alınan yağmur duası yapan bir şamanın duası arasındaki benzerlik dikkat çekicidir:

Kayra Kan! Kayra Kan! / Alas! Alas! Alas! / Avuç içi kadar açık ver! / Çuvaldız kadar deşik ver! / Asil kişinin torunuyum! / Sedir ağacının köküyüm, / Abu Tobu diye çağırdım, / Ongustay Kuldurak diye çağırdım, / Göğün göbeği yerde olsun! / Yerin göbeği gökte olsun! / Paştıgan dayımı çağırıyorum, / Göğün yolunu aç! / Avuç içi kadar açık ver! / Çuvaldız kadar deşik ver! / Yüksek dağın arkasından geç!/ 
Abakan dağının başından geç! / Kayra Kan, ey Kayra Kan / Alas, Alas, Alas!

(Çoruhlu, 1999: 90)

Kamagan Derviş’in "Allah" "Tanrı" ve "Çalap" kelimelerini bir arada kullanması bu bağlamda dikkate değerdir. "Çalap" kelimesi Türklerin İslamiyet'e girmeleri öncesinde tanrı kelimesi ile birlikte Allah lafzını karşıladıkları bir kelimedir. XV. yüzyıl başlarında Kur'an tercümesinde bu kelimenin Allah lafżını karşılamak için kullanıldığı bilinmektedir (Topaloğlu, 1995: 411). Bunun yanında Kamagan Derviş, Ülgen ismini de anmaktadır ki bu da Orta Asya inanç sisteminin bir yansımasıdır. Çoğunlukla insan şeklinde düşünülen Ülgen'in, göğü, güneşi ve ayı yarattığına inanılmışır. Bunların yanında Ülgen'in insanların ve hayvanların başlarını, kirpik ve göbekleri ile insanların yaşayacakları yerleri de yarattığına inanılmıştır (Çoruhlu 2011: 30-31).

Bir iyilik ilahı olan Ülgen ay, güneş ve yıldızlardan yukarıda yaşar. Ülgen'in bulunduğu yere uzanan yoldaki engelleri ancak şaman aşabilir. Erkek şaman yalnızca engellerden biri olan Altun Kazguk ya da Demirkazık denilen Kutupyıldızı'na kadar ulaşabilir. Bazı tasavvurlarda onun göğün yedinci, dokuzuncu ya da on altıncı katında oturduğu belirtilmektedir (Çoruhlu 2011: 29).

Kamagan Derviş’in "ulu 1şık" kavramına yer verdiği görülmektedir. Orta Asya inanç sisteminde çok sık karşılaşılan bir motif olan 1şık, Türk destan kahramanlarının doğduğu bir kaynaktır. Buna göre Oğuz Kağan destanında Oğuz'un Gün, Ay ve Yıldız ismindeki oğulları gökten inen mavi bir 1şıktan dünyaya gelmişlerdir. Oğuz, güneş 1şığından ortaya çıkan Bozkurt'un kılavuzluğunda dünyanın fethine çıkarken gökyüzü ışığından yeryüzüne inen Kut Türk mitolojisinde kutsal ve gök ile ilgili varlıklar arasında yer alır (Beydili, 2005: 255).

Yarhisar tekfurunun kızı Lotüs, Orhan Bey’e neden bir hisar yaptırıp eşyalarını burada saklamadıklarını sorar. Orhan Bey'in buna cevabı şu şekildedir:

Hisar kısmı tehlike yoksa bekler adamı... Geriden büyük yardım gelecekse bekler. Hisarımız var, zorlu düşman geldi, kapandık diyelim... Nerden gelecek bize imdat? Allah'tan diyeceksin... Allah kısmı kurban olduğum, her sıkıştığın kertede yetişmez... Neden? Düşünürüm hep... Yetişmez çünkü, her zaman düşman haksız olmaz besbelli, sen de bilir bilmez, kendini haksız düşürürsün... (...) (Tahir, 2004; 394)

Orhan Bey’in yukarıda "Allah kısmı" ifadesi dikkate değerdir. Gök Tanrı kavramı etrafında sistemleşen eski Türk inancında Gök Tanrı, göğün enginlik ve sonsuzluğunu ifade ettiği gibi onun resmi ya da heykeli de yapılamamaktadır. Burada "gök", göğün renginin yanında kutsallık ve yüceliği de ifade etmektedir. Bu bağlamda Gök Tanrı yüce ve ulu Tanrı 
anlamına gelmektedir (Beydili, 2005: 543-544). Eski Türk dininde ulu varlığın yanında ondan daha aşağı seviyelerde ve onun gücüne şüphe düşürmeyen kutsal varlıklar, iyeler, ruhlar ve evliyalar var olmuştur. Türk inanç sisteminde en ulu varlık olan Tanrı'dan başka koruyucu tanrıların varlığına inanç, çoktanrılı bir Türk dinini düşündürmüştür. Tanrı katından daha aşağıda kabul edilen bu varlıklar tek ve ortağı olmayan Türk tanrı inancının çoktanrılıymış gibi değerlendirilmesine sebep olmuştur (Beydili, 2005:541-542). Bu noktada Beydili şu açıklamada bulunur:

Hâlbuki birçok tanrıdan bahsedip "tanrılar" diye adlandırdıkları bu varlıklar, Yunan ve Rumların dininde olduğu gibi, Türklerde bir tanrılar topluluğu oluşturacak tek genel bir sistemde birleşmemişlerdir. Yani "Eski Türk panteonu” ifadesi de hiçbir şekli de geleneksel Türk cemiyetinde etnik kültürün ayrılmaz bir parçası olan din anlayışını tanımlayamıyor (Beydili, 2005: 541).

"Kamagan Derviş" isminin kendisi İslam öncesi ve sonrası Türk inanç sisteminin bir aradalığını ifade etmektedir. Eski Türklerde ülkenin yöneticisi olan kağan aynı zamanda din adamı görevini de yerine getirmekteydi. "Kamgan" adı verilen bu kişiler din ve dünya egemenliğini bir araya getirirler, devletin lideri olduğu gibi şaman törenlerini gerçekleştirirler. Göktürk Devleti’nin kurucusu Aşina bu özelliği kendinde toplamıştır ( Beydili, 2005: 290). Beydili bu noktada şunu ifade eder:

İşlevi eski Oğuzlarda yaygın şaman işlevine yakın olan Bayındır Han'ın atasının "Kamgan" adı, onun Türklerde hem dinî hem de dünyevî egemenliği kendi içerisinde taşıyan olduğunu gösterirdi. Yani hem hakan hem de din âyinlerini yöneten bir kâhin pozisyonundaydı. Dede Korkut kitabındaki "Kamgan" da bu eski görüşlerin izini yaşatırdı (Beydili, 2005: 291).

"Derviş ve dervişî kelimeleri, erken bir dönemden itibaren zâhidi ve zühdü, sûfîyi ve tasavvufu ifade etmek üzere Arapça' daki fakîr ve fakr kelimelerinin yerine kullanılmış, zamanla daha farklı ve daha geniş bir muhteva kazanmıştır" (Yazıcı, 1994: 188) diyen Tahsin Yazıcı, dervişliğin riyazet ve mücahede ile başladığını belirtir. $\mathrm{Bu}$ dönemde derviş, yeme, içme, konuşma ve uyumayı en aza indirirken ibadet, zikir ve tefekkür faaliyetlerini arttırır. Bu yol ile derviş nefsine hâkim olur (Yazıcı, 1994; 188).

IX. yüzyıldan itibaren İslam ile uyuşmayan kimi davranışları ve düşünceleri sergileyen şeriat ulemasınca İbâhiyyeci şeklinde adlandırılan derviş çeşidi ortaya çıkmıştır. Böylece İslam dünyasında iki derviş türü varlığını sürdürmüştür. Bunlardan birinci türü kendi kendine yeten, miskinliği ile övünürken yoksulluğunu çıkar elde etmek için kullanmayan derviş tipidir. Sahte dervişler ise dilenciliği geçim kaynağı olarak kullanan, dinin emir ve yasaklarına aldırış 
etmeyen dervişlerdir. Dinî sorumlulukların kendilerinden düştüğüne inanan bu dervişler, ahlak kurallarını göz ardı eden, kendilerini ermiş gösteren, büyü yapan insanlardır (Yazıcı, 1994: 188-189).

"Marjinal durumuyla seçilen dervişin yaşadığı yer, kaotik karakterli bir bölge olabilir" (Beydili, 2005: 167) diyen Beydili, kürk giymiş, çıngırak takmış derviş tipinin şaman kültürünün izlerini taşıdığını belirtir. Şaman'ın eski inançta yerine getirdiği görevleri zamanla derviş üstlenmiştir. Anadolu Türkmenleri içinde saygı görmelerinin altında da dervişlerin şamanlar ile birlikte düşünülmesinin etkisi vardır (Beydili, 2005: 167). Bu bakımdan "Kamagan Derviş" isminin kendisi de romanda İslam öncesi ve İslami Türk inancını yansıtması nedeniyle altı çizilmesi gereken bir özelliktir.

Kara Vasil'in oğlu ve Issızhan'1 ablası ile işleten Mavro, ablası Liya'nın Bacıbey'in oğlu Kerimcan'ın ağabeyi Demircan ile birlikte Notüs Gladyüs tarafından öldürülmesinin ardından bu ölümde parmağı olduğu düşüncesiyle Karacahisar tekfuru Aksantos’un kardeşi Filaytos'un işkencesine maruz kalır. Liya'ya bağlanmış Osmanlı sarığının hesabını sormak için Osman Bey'in yanına gelen Filaytos'un elinden Mavro'yu Bacıbey kurtarır ve daha sonrasında Mavro, Müslüman olur. İslam dinine yeni girmiş olan Mavro, Hıristiyanlığa ve Müslümanlığa ait inanç kalıplarını bir arada kullanmaktadır. Mavro, ablasının katilleri Notüs Gladyüs ve Uranha'yı bataklıkta takip etmektedir. Kanlı Boğaz denilen bataklık alana geldiğinde Mavro, istavroz çıkarırken "bismillah" demeyi de ihmal etmez. "Mavro, Ortodoks istavrozu çıkarıp kılıcını 'bismillah' diye yoklayarak Kanlı Boğaz'a girdi. Hem evine gelmiş gibi güvenli, hem de Boğaz’’n her türlü kalleşliğine yatkın olduğunu bildiğinden, tedirgindi” (Tahir, 2004: 570).

Kocası şehit düşmüş, oğulları Demircan ile Kerimcan'1 yetiştirmiş Bacıbey, toplum içinde itibarı olan biridir. Karacahisar'ın alınmasının ardından Bacıbey'in sergilediği davranış bir başka ikiliğe örnektir. Osman Bey, Şeyh Edebali'nin olur demesiyle Karacahisar üzerine yürür ve köylüden üç ölü, ikisi ağır on yaralıyla Karacahisar'ı alır. Bu müjdeli haber üzerine sevinçten alacaklar bağışlanmış, kavuşamayan gençlerin evliliklerine onay çıkmıştır. Bacıbey de dört savaşçıya evinde ziyafet verecektir ki sofrasında şarap da vardır.

Bacıbey'in yaşadığı ikiliği Kerimcan da Mavro ile birlikte yaşar. Kerimcan, Yahşi İmam'ın yanında din eğitimi almış ve Şeyh Edebali'nin tekkesine yerleşme hayalleri kurmuş biridir. Mavro ise İslamiyet'i kabul edip Sögüt'te Osman Bey'in himayesinde hayatını sürdüren bir Rum'dur. Bu ikisinin de dâhil olduğu kuşatmanın ardından Türkler, Bilecik Hisar'ını alırlar. Ne var ki bu kuşatma sırasında Söğüt’ten Şirin Kız şehit olur. Şirin Kız'ın cenazesi şehit olması nedeniyle yıkanmadan defnedilir. 
- Burada misin yahu? Araya araya!...

“Çok şükür Mavro’ymuşum!” diye gülümseyerek omuzundan baktı:

- Buradayım! Sen nerdesin?

-Fıkara Şirin kızı gömecekler... Savuştum.

- Hocasiz mocasiz mi?

- Şehit olduğundan, yıkanması namazı olmazmış... Bir yandım ki Şirin bacıya

(Tahir, 2004: 546).

Bir süre sonra Popolina isminde, Bilecik Hisarı'nda çavuş olan birinin beslemesi gelir. Popolina yanında şarap da getirmiştir. Mavro, kızın elinden kupayı alır ve Kerimcan'a verir. Kerimcan biraz içer şaraptan ama yüzünden anlaşıldığına göre şarapla arası hoş değildir. Mavro ise bir dikişte kupayı boşaltır. Burada dikkat çekici nokta gaza duygusuyla düşman hisarını ölüme meydan okuyarak alan bu iki gencin az önce şehit düştüğüne inandıkları Şirin Kız defnedilirken şarap içmekte bir beis görmemeleridir.

\section{Toplumsal Çürüme, Din ve Din Adamları}

Romanda toplumda görülen çürüme, din ve din adamları paralelinde anlatılmaktadır. Yazar, öncelikle toplumu oluşturan bireyler nazarında din adamlarının pek de rağbet edilen bir konumda olmadığını ifade etmektedir. Savaşçılıkla kıyaslandığında din adamlığının daha düşük bir konumda olduğu belirtilmektedir. Yerleşik hayata geçmemiş, varlığını savaşmaya borçlu bir toplumun mollalık müessesine bakışını Bacıbey ile Aslıhan arasındaki konuşmada görmek mümkündür. Aslıhan, Bacıbey'in oğlu Kerimcan ile beşik kertmesidir. Buna karşın evlenememektedirler. Bunun sebebi ise Kerimcan'ın dinî ilimlere merak salmasıdır. Bu durumu Aslıhan evlenmeleri için engel görmektedir. O, savaşçı olmayan biri ile evlenmemekte kararlıdır:

- Sen mollaya da varırsın ya, hani dileyip alan?

- Şimdi yanıldın Bacıbey! Silah ustası Kaplan Çavuş’un kızıyım ben, Tanrı tanık, beli kılıçlı olmayan, bizim eşiğimizi aşabilemez. Çünkü bizim soyumuzda, kılıç taşımayanı erkek saymak yoktur.

Aslıhan, son sözleri şakadan biraz çıkarmıştı. Ötekiler ürkek, Bacıbey'in kızıp köpürmesini beklediler. Küçük oğlu Kerim'in molla olmak istemesini önlemek için, ne kadar çabaladığını hepsi biliyordu. Demircan'ın bir Rum kızına tutulmasından daha çok üzülüyordu buna... Babasının savaşçlık ününe Kerim'in sürdüğü lekeyi önlemekte Demircan'ın gereği kadar kendisini arkalamadığı içindi, Liya kızın Müslüman olmasını şart koşması... 
Bacıbey, karıların bekledikleri gibi Aslıhan'a kızmadı, tersine sert bakışlarından acımaya benzer bir yumuşaklık geçti. Kerim yüreksizi mollalığa sapınca, bu edepsiz Aslıhan'ın ne kadar şaşırdığını, nasıl gizli gizli ağladığını biliyordu. "Savaşçı olmayana varmam" demişti bikez, el kadar bebeyken... Hem inatçıydı, hem de sözünü geri yutmayacak kadar onurlu...(...) (Tahir, 2004: 109).

Kaplan Çavuş, kılıç eğitmeni aynı zamanda Kerimcan'ın evleneceği kız Aslıhan'ın da babasıdır. Kerimcan, bütün planını molla olmaya, Şeyh Edebali’nin tekkesinde dinî ilimlerle uğraşmak üzerine kurmuştur. Lakin ağabeyi Demircan'ın öldürülmesinin ardından annesi Bacıbey, onun savaşçı olması yolunda 1srarcı olur. Bunun üzerine Kerimcan, annesinin bu isteğine dayanamaz ve savaşçı olmaya karar verir. Kaplan Çavuş, onun eğitimini üstlenir. Bu sırada Kaplan Çavuş’un ifadelerinden imamların miskinliğinin genel kabul gördüğü anlaşılmaktadır: "-Çevir! Olmadı. Çevirmenle, kirişin ilmeğini kancasına yetiştireceksin ki, köpoğlu yay, gerilmiş bula kendini de, neye uğradığını bilemeye! Hadi beraber! Çevir! Oğlum Kerim, çelebilik istemem. Defliyemedin Yahşi İmam'dan öğrendiğin miskinliği... (...)” (Tahir, 2004: 185).

Kerimcan kendisini ileride molla olacak, Şeyh Edebali'nin yanında yer alacak bir din adamı gibi yetiştirmeye çalışmış, savaşçı olmayı adeta ağabeyi Demircan ve annesi Bacıbey'e devretmiştir. Ne var ki ağabeyi Demircan'ın kurulan bir pusuda öldürülmesi üzerine annesi onun savaşçı olmasında 1srar eder. Hatta ona bu yolda şiddet uygular. Söğüt’te Köslük toplantıs1 yapılacaktır. Buraya Söğüt'ün savaş̧̧ları gelecektir. Kerimcan annesinin 1srarı ile savaşçı elbiselerini giyer ve bu toplantıya katılır. Burada hangi grubun içinde savaşçı olarak yer alacağını düşünürken dervişlerin o dönemde içinde bulunduğu bozulmanın da altını çizer:

Kerim, acı acı gülümseyerek kılık beğenmekten vazgeçti. Bu kez de takımlardan hangisinin savaşçılıkta daha çok saygı gördüğünü araştırdı. Dervişler, birbirini hiç tutmayan inançları, davranışları, sözlerinin yaptıklarına uymaması yüzünden, çevrede eskiden beri güvenilir savaş̧̧ı sayılmıyorlardı. Bunların dervişlikleri gibi, savaş̧̧ılıkları da yarımdı. Dünyayı büsbütün boşlayıp ahrete yönelmedikleri gibi, kendilerini toptan dünyaya verip cennetten de vazgeçmiyorlardı. Dillerinde "Bir lokma - bir hırka" lâfını düşürmedikleri halde, savaşlardan sonra "zaviyemize, tekkemize vakıf isteriz" diye bey eşiklerini aşındırmaları bundandı (Tahir, 2004: 125-126).

Yazar, Daskalos Derviş'in hal ve hareketlerinden söz eder. O, Ertuğrul Bey'in kardeşi Dündar Bey'in yanında yer almış, onun sözcüsü durumundadır. Dündar Bey, Ankara'dan İznik'e Kütahya'dan Bolu'ya bölgenin en varlıklı insanı olarak bilinmektedir. İstanbul'un Cenevizli bezirgânlarında binlerce altınını işlettiği söylenen Dündar Bey, Rum abdalları ve bazı 
dervişlerden çapul sonunda ucuza aldığı malları ve körpe esirleri, sonrasında pahalıya satarak servetini arttırmaktadır. $\mathrm{Bu}$ nedenle de Ertuğrul ve Osman Beylerin korunmasına önem verdikleri barışın varlığından rahatsız olmaktadır. Böyle bir kişiliğe sahip Dündar Bey'in yanında yer alan ve derviş ismini taşıyan Daskalos'un yazar tarafından anlatımı ise ilginçtir:

Dündar biraz pepeme olduğundan toplantılarda kendi konuşmuyor, Daskolos Derviş’i öne sürüyordu. Daskolos, İznik Ayasofyasının başpapazının biricik oğluydu. Papaz çömeziyken şarapçılığa, karıcılığa, sonra da kumarcıllğa vurmuş, serseriliğinden usanıp harçlığını kesen babasına acı çektirmek için din değiştirip Yusuf adını almıştı. Bir zaman çıplanıp avuç avuç afyon yiyerek abdallarla gezdi tozdu. Sonra, ne düşündüyse düşündü, savaşçı dervişlere katıldı. Katılmasıyla da, işi büsbütün azııı kapkara yobaz kesildi. Akınlarda, eski dindaşlarına, akıl almaz eziyetler ediyor, canlı malların götürülemeyenlerini öldürüp cansızlarını keyif için ateşe veriyordu. Uçlarda eski Müslümanlarla yeniler arasında kıdem ayrıntısı gözetilmediğinden, edepsizliği arttırdıkça arttırmış, hele Dündar Alp'a kapılandıktan sonra güç yetesi kalmamıştı. Cin gibiydi. Ağzı lâf yapıyor, ayetten, hadisten, evliya kerametleri hikâyelerinden başka "Bunlar da Allah'ın kitabıdır" diye Tevrat'1, Zebur'u, İncil'i de araya karıştırıyordu. Birkaç kez büyük caminin hocası Yahşi İmam'a bile sırtarmış, gerçekten din bilgini olan Hocayı, yalınkatlık, biraz da gevşeklikle karalamaya kalkmıştı.

Şimdi iki dizi üstünde, Kur'an okur gibi sallanmakta, kim bilir ne domuzluklar tasarlamaktaydı. Sakalı Frenklerinki gibi sivri, boynu burulup kolayca alınacak kadar inceydi. Domuzuna şarap içtĭgi, Ertuğrul Bey'in yasaklamasına aldırmadan, abdallara, dervişlere, Germiyan toprağından aralıksız afyon getirdiği, kısır karılara doğurma hapları, ırz düşmanlarına sıcaklık muskaları yazdığı biliniyordu (Tahir, 2004: 131-132).

Osman Bey'in sözlerinde o dönemde dinî kendi çıkarları için kullanan insan tipinin varlığg sezilmektedir. Osman Bey ile Kerimcan, Şeyh Edebali'nin yanına giderken konuşurlar. Bu konuşmada Osman Bey, bir kısım cavlağın kendini dindar göstermeye çalışan insanlardan oluştuğunu ifade eder. Kerimcan'a "Ülkede güven kalmadığı için, kapısız kalan levendler derviş-aptal kılığına girer oldu. Çoğu cavlağa soyunmakta bunların..." (Tahir, 2004: 160) diyen Osman Bey, Şeyh Edebali’nin yanında Argun İlhan'ın Bizanslı prenses alma isteğini anlatırken yine din adamlarının haline dokundurmada bulunmaktadır: “-(...) Asıl önemlisi, Argun İlhan, bir İslâm ülkesini, kâfir karısı almak için düşmanlarına bağışlamayı göze alamadı. Bunu kitaba uyduracak dinî bütün (!) bilgisi derin bir müftü bulamadı. (...)" (Tahir, 2004: 166-167). 
Din adamlarının devlet yönetimindeki, diğer bir değişle dünya işlerindeki, tutumları Kerimcan'ın gözünden değerlendirilmektedir. Kerimcan, Osman Bey'in Şeyh Edebali'nin kızı ile evleneceğini Orhan Bey'e söyler. Orhan Bey'in sevindiğini görünce oldukça şaşırır. Orhan Bey’e annesinin ne diyeceğini sorar. Orhan Bey, babasının şeyhe damat olmasının ne kadar önemli olduğunu, buna annesinin bir şey demeyeceğini ifade eder. Devlet yöneticisi ile bir din adamının bu denli birbiri içine girmiş hayatları karşısında Kerimcan hayretini saklayamaz:

(...) böyle devlet kimin eline geçer bu zamanda? -Eleğini kurtarıp telâşla koştu, kapıda durup döndü- Dünyadan haberin yok, molla Kerim, dünyadan hiç haberin yok...

Kerim, cirit değneklerine bakakalmıştı.

Haberi olmadığı bu dünyada, şeyhler beylerden damat, beyler şeyhlerden kaynata arıyorlardı. Haberini kendisinin taşıdığı birtakım işler dönmekteydi ki, anlayana aşk olsun! (Tahir, 2004: 207-208).

"Arapça'da kazâ (kadâ) kökünden ism-i fail olan kâdî, fikıh terimi olarak insanlar arasında meydana gelen çekişme ve davaları şer'î hükümlere göre çözümlemek için yetkili makamca tayin edilen kişiyi ifade eder" (Atar, 2001: 66) şeklinde açıklanan kadılar, insanlar arasında meydana gelen hukuki anlaşmazlıkları hükme bağlamakla görevli kişilerdir. Kadılar İslam tarihinde imam-hatiplik, maliye ve eğitim ile ilgili görevleri de yerine getirdikleri gibi onların halife ile vekâlet ilişkileri vardır. Kimi dönemlerde kadı olabilmek için müctehid seviyesinde din âlimi olunması şartı dahi tartışma konusu olmuştur (Atar, 2001: 67). Kadıların taşıması gereken özellikleri Fahrettin Atar şu şekilde ifade eder:

Fakihler, kadılık nitelik ve şartlarından başlıcalarını sıralarken hukukî işlemde bulunmak için gerekli diğer şartlara ilâve olarak kadı tayin edilecek kimselerin derin hukuk bilgisine, vücut bütünlügüne, sosyal ilişkilerin gereklerini, halkın ihtiyaçlarını, örf ve âdetlerini kavramaya elverişli kültüre, dış etkilere karşı koyacak derecede ahlâk, karakter ve seciyeye sahip olmaları, dinî emir ve yasaklara aykırı davranışlarda bulunmamaları gerektiğini ifade ederler (Atar, 2001: 67).

Romanda kadıların içinde bulunduğu hâl Eskişehir Sancağı kadısı Hophop Kadı bağlamında ele alınır. Eskişehir Sancakbeyi Alışar Bey, Hophop Kadı'nın yönlendirmesiyle Osman Bey için Balkız'ı Şeyh Edebali'den isteyecekken kendine ister. Şeyh Edebali bu isteği kabul etmez. Bu durum Alışar Bey'in adının lekelenmesine sebep olduğu gibi Osman Bey ile dostluğunu da bitirir. Bunun üzerine yazar, onun Hophop Kadı ile tanışmadan önceki hâlini anlatır. Alışar Bey, kendi yönetiminde rüşvetin alınmasına ve verilmesine müsaade etmeyen, 
ahlaksızlığın her türlüsünü şiddetle cezalandıran, yöneticilerinin halkın malını haksızlıkla kullanmasina engel olan biridir.

Hophop Kadı (Darendeli Hüsamettin Efendi) geldikten sonra Alışar Bey değişmeye başlar. Hophop Kadı, Alışar Bey’e değişik fikirleri dayatmaktadır. Hophop Kadı, öncelikle halka önem verilmemesi gerektiğini, halkın kendi çıkarının ne olacağını bilmekten uzak olduğunu vurgular. "Sözüm kanun olsun dersen, keyfine kimseyi karıştırmayacaksın” (Tahir, 2004: 258) diyen Hophop Kadı, halka karşı kıyıcı olmazsa halkın onun "verimkârlığının” ve "bağışlayıcıllğının” değerini bilemeyeceğini söyler. Halkın elindeki akçeyi almayı beyliğin hazinesini doldurmayı tavsiye eder.

Alışar Bey, Hophop Kadı'nın yönlendirmesine karşı çıkar. Bunun üzerine Hophop Kadı, Pervâne Subaşı ile işbirliği yapar ve düzenini sessiz sedasız kurar. Öncelikle tefeciler elindeki borç senetlerini tefecilerden onları korkutarak alır. Sipahilerden tımarlar yok pahasına alınır. Ülkede bütün kadılar rüşvet alırken o rüşvet vererek işlerini halletmeye başlar. Devlet vergisi olarak toplanan aşar ekinlerini, depoda üç y1l beklemesi gerekirken o, Ermeni tüccar aracılığıyla Frenk gemilerine satar. Bunlara ikinci yıl yine devlet vergisi olarak toplanan deriler, urganlar, dokumalar, hammaddeler ve madenler de eklenir. Kendi zenginleşirken Alışar Bey'in de gönlünü alırcasına onun borçlarını da öder. Yazar, Hophop Kadı üzerinden dönemin kadılarının ahlaki düşüklüğünü şu şekilde ifade etmektedir:

Oysa Darendeli Hüsamettin Efendi de, zamane kadılarının çoğunluğu gibi gizli içmek şartıyla şarapçı, dile düşmemek şartıyla biraz karıcı, biraz oğlancı, yerine göre doymaz rüşvetçi, parayı çok vereni haklı çıkaran Selçuk kadılarındandı. Zamana uygun, üst üste denenmiş birkaç görüşü vardı: "Ağzı olan yer! Yedirmesini bilmeli!", "En gem almaz adamın yuları: pohpoh!”, "Halkı yıldırmadıkça nesne hasıl olamaz" (Tahir, 2004: 257).

Devlet yönetimindeki ahlaksızlıkları yanında Hophop Kadı'nın insanların dinî duygularını kullanma özelliğinin de altını çizer yazar. İslam inancında yasak olan büyü yapımını da gerçekleştiren Hophop Kadı, Balkız'a tutkun olan Alışar Bey için Balkız’a büyüler yapmıştır. Bunu yaparken bu işi sıradan bir düzeye indirmesi de diğer ilginç bir noktadır:

- Ya taşıdığın bunca sıcaklık muskaları, yakınlık muskaları?.. Yarasa kemiğinden, tosba kabuğundan tılsımlar!...

- Eh, o kadarı da, bizim sana ahret kardeşi arkalaması... Müslüman Müslümana, zor yerde hiç mi yardıma yetişmeyecek? (Tahir, 2004: 272) 
Yazar, din adamlarının yaptıkları ile insanlara ürküntü verdiğini ima eden ifadelere yer verir. Alışar Bey, Hophop Kadı ile Anadolu halkının durumu hakkında konuşurken şu ifadelere yer vermektedir: "Buraların sipahisi fukaralıktan güçsüz düşmüştür, çoğu, kapısız levende karışıp eşkıya bölük başılığına geçmiştir. Birazı dervişe, alaka soyunup, bir lokma bir hırka için tekkelere sığınmıştır. Kalanı da, reayanın çoğunluğu gibi tefeci elindedir. Tefecinin çoğunluğu vazifeli ya da emekli kapı kuludur. Şeyhtir, senin gibi kadıdır” (Tahir, 2004: 259). Halkın şeyh ve haçlı elinde soyulduğunu ifade eden bu sözlerin yanında Moğolların dahi din adamı kesiminden çekindiğini ifade eden sözlere de yer verilmektedir.

Alışar Bey, Hophop Kadının yönlendirmesi ile Şeyh Edebali'nin kızını kaçırtmaya niyetlenir. Bu iş için de Moğol Çudaroğlu ile anlaşacaklardır. Çudaroğlu, Alışar Bey'in sarayına geldiğinde Hophop Kadıdan çekinmesi dikkat çekicidir: "Kapıyı Pervâne Subaşı açmış, kanadı ardına dayayarak konuklara yol vermişti. Çudaroğlu, Hophop Kadı'yı görünce bir an durakladı. Moğol da, başı sarıklılar karşısında, tıpkı Anadolu insanının Moğol karşısında duyduğu ürküntüyle irkiliyordu" (Tahir, 2004: 273).

Orhan Bey'in evinde cariye olan Şirin, ahırdaki Kerimcan'1 Orhan Bey zanneder ve Orhan Bey'in otuzlu yaşlarında dul Pakize ile ilişkisini hatırlatayım derken bunu Kerimcan'a söylemiş olur. Her ne kadar Pakize, Ertuğrul Bey tarafından başka bir köye evlendirilerek gönderilmiş olsa da toplumdaki çürüme Kerimcan'ın hayretine sebep olur. Kerimcan ahlaki çürümenin hayretini yaşarken bunun daha kötüsünün din adamlarının bulunduğu yerlerde yaşandığının da altını çizer:

(...) Kitabın yazdığına göre, cariye kısmının efendisine karşı savunacak ırzı olmaz, aralarındaki birleşme, nikâksızca bile günah sayılmazdı. Pakize'ye geldi mi, burda suç on iki yaşındaki çocukta değil, otuzuna yaklaşmış dul karıdaydı. Kısacası, karının çok olduğu yerde, böyle rezilliklerin, ne kadar uğraşılsa önü alınamıyordu. "Bunun daha kötüsü, medreselerde, tekkelerde, kimi ahi topluluklarında, gâvurların manastırlarında, şövalye tarikatlarındaki oğlancılık!...( Tahir, 2004: 322)

Yazar iki durumu bir arada vermek suretiyle bunların birbirleri arasındaki benzerliği sezdirmektedir. Söğüt halkı yaylaya çıkmaktadır. Bu kalabalığın içinde Yarhisar tekfurunun kızı ve Orhan Bey'in sevdiği Lotüs de bulunmaktadır. Bu grubun içinde Kel Derviş, Cimri'nin başına gelenleri anlatmaya başlar. Moğol, Konya'yı basmış ve sultanı Tebriz’e götürmüştür. Karaman beyi de Cimri'yi Konya sultanının mirasçısı olarak Konya'ya getirir ve Cimri yaptığı mücadele ile halkı kendisinin sultanın varisi olduğuna inandırır. Bunun ardından Cimri, tahta çıkar çıkmaz halktan haraç almaya başlar. Durumu öğrenen Abaka İlhan Konya'ya gelir, Karamanoğlu ve kardeşlerini boğdurur. Oradan kaçan Cimri ise ayağındaki meşinden sultan 
çizmesini çıkarmadığı için tanınır, diri diri derisi yüzülür ve derisine saman doldurulup karg1 ucuna çıkarılır.

Cimri ve diğer devlet yöneticilerinin dünya hırslarının anlatıldığı satırların hemen ardından yazar, Şeyh Edebali ve Osman Bey'in meydana gelişini ve özellikle de Şeyh Edebali'nin giyimini tasvire başlar. Burada yazar, dünya malının çekiciliğini Cimri ve Şeyh Edebali’nin nezdinde yansıtmış olur:

Meydanın giriş yerine bakarak susunca dinleyenler de döndüler.

Önde Osman Beyle Şeyh Edebâli, Akçakoca, arkalarında Söğüt'ün yaşlıları, geliyorlardı. Şeyh Edebâli ünlü ak katırına binmiş, büyük ahi derneklerinde omuzuna aldığı içi samur kaplı yeşil çuhadan uzun cüppesini giymişti. Ahi şalvarının altında sarı sahtiyandan yumuşak çizmeleri vardı. Horasan sarığıyla bir kat daha büyüyen kocaman kavuğunu, nasıl olup da bu kadar kolay taşıdığına şaşmamak mümkün değildi. Birlikte yaylaya çıktığı Türkmen'lerin şerefine halis Buhara şalından kuşağına iki arşın ahi palasını sokmuştu. Katırın eğeri, başlığı, hele üzengileri gerçek sanat işiydi. Göz alıcıydı (Tahir, 2004: 405).

Farsçada Hristiyanların âlim, zahit, ileri gelen din adamlarını karşılamak için kullanılan bir kelimedir keşiş. Yaşam şekilleri bakımından keşişler ikiye ayrılmaktadırlar. Birinci gruptaki keşişler çöle, ormana, dağa tek başlarına çekilen hiç kimseyle görüşmeyen din adamlarıdır. İkinci gruptaki keşişler ise manastırda cemaat ve tarikat disiplini içinde yaşayanlardır. Orta Doğu milletleri içinde Hristiyanlık öncesinde de zühdü esas alan bir yaşam şekli olmakla birlikte Hristiyanlık tarihinde keşişlik müessesesi III. yüzyılda Mısır'da çölde münzevi hayat yaşayan Aziz Antony ile başlamıştır. Anadolu'da ise 379 yılında ölen Caesarealı Basil ve kız kardeşi Macrina’nın çalışmalarıyla yaygınlaşmıştır (Gündüz, 2002: 322-323). Keşişlerin sahip olması gereken özellikleri Şinasi Gündüz şu şekilde ifade etmektedir:

Bütün keşişlerin uyması gereken kuralların başında yoksulluk, alçak gönüllülük, bekârlık ve iffet gibi ihtirasları kırmayı, teslimiyet ve alçak gönüllülüğe teşvik etmeyi amaçlayan hususlar gelir. Keşişlerin mal mülk edinmesi, dünyaya bağlanması hoş karşılanmaz. Manastırda yaşayan keşişler cemaat kurallarına uymak ve bir yol göstericiye itaat etmek zorundadır. Öte yandan sessizlik, meditasyon, tefekkür, dua, oruç ve nefis terbiyesi gibi hususlara riayetle ilgili, uygulayana ve geleneklere göre değişiklik arz eden kurallar da bulunmaktadır (Gündüz, 2002: $323)$.

Devlet Ana romanında keşişler kendilerinden beklenen davranışlardan çok uzak bir biçimde anlatılırlar. Söğüt yaylaya çıkarken onlara pusu kurulduğu haberi alınır. Mavro, bunun 
üzerine halkın içinde Eskişehir ve Karacahisar tekfurlarına, Çudaroğlu çetesine, Frenklere bunu bildiren birinin olduğunu düşünür. Bu kişinin de bulunduğu bölgede savaş çıkmasını arzulayan bu uğurda dinî kullanmaktan çekinmeyen Benito Keşiş olduğunu ifade eder. Mavro bu tahminini dile getirirken din adamlarının güvenilmez olduğuna dair kanaatini de ifade etmiş olur:

(...) Kötülüğün baş1... Rahmetli babam derdi ki, "Her bulaşık işte karı parmağı arayacaksın, oğlum Mavro." derdi, "Karı parmağı göremezsen, papaz parmağı arayacaksın.” derdi. Yutkundu-: Nasıl etsek de arkadaş... Şu Benito Keşiş’in inini birine yoklatsak... İki dinim gibi bilmekteyim ki, rezilliğin izi burdadır (Tahir, 2004: 429).

Bunun üzerine Kerimcan kendisinin bu mağaraya gireceğini söyler ve Mavro'dan da gözcülük yapmasını ister. Mavro, Benito Keşiş’in büyüler yapmış olabileceğini, tılsımlarla insanı eğip bükeceğini ifade eder. Onun bu korkusuna Kerimcan'ın karşılığı ilginçtir: “Meraklanma akılsız gâvur!... Biz de medresede okuduk az biraz... Keşiş dişi, yırtamaz molla derisini... Zehirimizin birbirine panzehiri vardır. Ferah ol! Hakkından gelirim ben, dua gücüyle, keşiş tılsımının ....(...)" (Tahir, 2004: 430).

Yazar, din adamlarının ahlaki düşüklüğünü Benito Keşiş ve Daskalos Derviş aracılığ ile dile getirir. Dündar Bey, yanındaki adalı Rum çocuk Balabancık’1 Benito Keşiş'in yanına öteberi göndermek için kullanmaktadır. Benito Keşiş, Balabancık’a tacizde bulunmaktadır. Bu sıkıntısını Balabancık, Aslıhan'a anlatır. Aslıhan bu durumu Dündar Bey'e söyleyip söylemediğini sorar. Balabancık da Daskalos Derviş'in Dündar Bey'in kendisine inanmayacağını, kendisini Moğol'a satacağını söyleyerek onu vazgeçirdiğini ifade eder. Daha ilginci ise Daskalos'un şu ifadeleridir: "'Allah adamıdır Benito pederimiz yavrum Balabancık' dedi, ‘gönlünü etmek günah değildir, sevaptır' diye güldü’' (Tahir, 2004: 508).

Kerimcan ve Orhan Bey, Kamagan Derviş’i ziyarete giderler. Orhan Bey, Osman Bey'in isteğini Kamagan Derviş'e iletir. Benito Keşiş'e gelenleri, Kamagan Derviş’in dinlemesidir bu istek. Bunun ardından bir kese Kamagan Derviş’in eline tutuşturulur. Bu durumu yazar, Kerimcan'ın gözünden değerlendirir:

Kerim dalgındı. Öz amcası Dündar Alp'e bunca yıllık dostu Rumanos Tekfur'un Osman Bey’i öldürmeye kalkışmalarından çok, dünyayı boşlayıp bir mağaraya sığınmış Kamagan Derviş’in para karşıllığ casusluk etmesine şaşıyordu. Kılıç kuşanıp bey kapısına yerleşmeseydi, Yahşi İmam'ın hizmetini görerek mollalığa çabalasaydı, dünyada böyle insanlar bulunduğundan habersiz mi yaşayıp ölecekti? Benito Keşiş de Tekfurlara elbet bedava çalışmıyordu. Bunlar, yurtlarını bırakıp, şu 
kadar bin fersahtan dönülmez gurbete çıkıp, gelip dă̆ başlarında birer mağara peydahlayıp "Say ki” birer dükkân açmışlardı. (...) (Tahir, 2004: 511).

Yazar, dinî temsil eden kişilerle daha dünyevi bir hayatı tercih eden kişileri yan yana getirir. Ünlü bir demirci ve silah ustası olan, tüfek yapmaya çalışan Kaplan Çavuş tüfek yapımıyla meşguldür. Kaplan Çavuş’un çocukluk arkadaşı Yunus Emre ise bu işi namertlik olarak değerlendirir. Enginün, "Kemal Tahir, Devlet Ana adlı romanında Yunus Emre'yi kapitalist düşüncenin karşısındaki bir iktisatçı gibi konuşturur" (Enginün, 2012: 102) dese de burada dindar kişinin uzak görüşten yoksunluğunun dile getirildiği de söylenebilir:

Doğrusu da neymiş bunun? Vah vah! Yazık! Anladım ve de yandım. Çünkü boşuna dolaştırmaktasın bunu sofrayı, Ozan Yunus! "Zağlı kılıç, demir temrenli ok, neyine yetmez?" dedindi aklında mı demincek? "Araya ateş tozunu, delikli demir rezilliğini sokaraktan, âdemoğluyla senin alıp veremediğin nedir, böyle rezil bir işe yumulup? diye çekiştirdi. "Dünyanın çivisi çıkar çünkü mertlik bozulur" dedindi. Hey kafa, hey bunu kafa!.. Sen, gezele bakalım, "Bize didâr gerek dünya gerekmez/Bize mâna gerek dâva gerekmez" diyerekten gezele! Karanlık Dünyanın Frenk tüccarbaşısı ne demeye getirmekte? "Altun dilerseniz işte altun... Alın çuvalla verin bize delikli demiri." demekte... "Ermişlik basamağına ayak basıp evliyalığa erişeceğim ve de gece gündüz göz süzerken cennet seyri sofrasına kavuşacağım," umusuyla dünyayı boşlamak çabalamasından, sefil Yunus Emre... Sırası hiç değildir oysa!.. Hayın düşmanın niyetine bak! Neyi verip neyi alacak? Demir fındığı serpip ve de göğsüme gümletip canıma kıydığı sıra altun bana kalkan olur mu? Olmaaaz! Müslümanı avanak bellemesi neden? Bizim avanaklığımız daaan... Biz bu işe kudurganlı̆̆ımız sebebiyle sıvanmadık. Ozanımız Yunus Emre, dünyaya ün salalım, diye hiç sıvanmadık. Ben mübarek kılıcı Aslıhan kızdan ileri sevmez miyim? Sen bilirsin, kimse bilmezse... Ya bizim aklımıza gelen Frenk ustasının aklına gelmez mi? (Tahir, 2004: 224)

Kaplan Çavuş, maddi bakımdan geri kalmış, düşmanının baskılarına karşı koyamayan bir toplumun manevi anlamda da zarara uğrayacağının altını çizer. Devlet Ana romanında savaş̧̧ı ve göçebe Türk toplumunun çoğunlukla din adamlarını olumsuz yönde değerlendirdiği vurgulanır. Bunun yanında din adamları maddi çıkarları doğrultusunda çoğu zaman ahlaki değerleri göz ardı ederek hareket eder. Devlet yönetiminde etkin din adamlarının yönetici kısmını olumsuz etkilerken onların dünyevi çıkarları doğrultusunda dinî hükümleri yorumlayabildikleri ifade edilir. Nefsi arzularını terk etmesi beklenen din adamlarının bunun aksine nefislerini tatmin yolunda her türlü ahlaksızlığı göze alabildikleri de belirtilir. $\mathrm{Bu}$ özellikleri ile din adamları ya da din adamı görünümündeki insanlar, toplumun içinde bulunduğu karmaşanın en önemli nedeni olarak gösterilir. 


\section{Yeni Müslümanların Benimsenme(me)si ve Gayri Müslimlere Bakış}

Romanda Müslüman ile Hristiyan arasında dostluğun Bacıbey tarafindan tepkiyle karşılandığı görülmektedir. Orhan Bey ile Kerimcan, Bacıbey'in kendilerini Hıristiyanlarla yakın ilişkileri olması nedeniyle eleştirdiğini ifade etmektedir:

Yeri cennet olsun, zamansız öldü baban... Bezdik yahu biz bu Bacıbey'in elinden... Geçende beni tuttu, "Dönmezköy'ün gâvur papazına "baba" demişsin, Bey kısmı, ağzından çıkanı bilecek... Bir daha duyarsam bak neler olur!” diye azarladı. Babama da, Bilecik tekfuruna "kardeşim" dediğinden çıkışmış... Yengenin yerinde olsam, "Döndüm dinimden" derim, eve yerleşirim! Sonra da "Yok dönmedim" deyiveririm (Tahir, 2004: 96).

Yukarıdaki ifadelerin devamında ise bir kısım insanların diğer Müslümanların imanını sorguladığı bunları yeniden imana getirecekleri anlaşılmaktadır: “- Doğrusu da bu... ağam elini tez tutmazsa, "Dinimden döndüm" demek de yetmeyecek! Tanrı korusun, beylik büyük amcan Dündar Alp'in eline geçti mi, derviş takımı, salt Rumları değil, bizi de yeniden imana çağıracak, duraklayanın boynunu vuracak..." (Tahir, 2004: 96) Bacıbey, her konuşmasında Hıristiyanlar ile kendisi arasına bir mesafe koymaktadır. Kaplan Çavuş'un kızı ve Kerimcan'ın beşik kertmesi Aslıhan, Bacıbey ile Bacıbey'in evlatlarının evliliğini konuşmaktadır. Demircan Bey’i evlendirmemesinin altını çizen Aslıhan'a Bacıbey'in ifadesi şu şekildedir:

-Demircan ağamı evermediğinden suç sende... Getir gelinimizi, beklesin evini, sokmasın oğlanları...

-Benim evime... gavur kızından gelin... Ya ben ölmüş müyüm? (Tahir, 2004: 108)

Sögüt'te insanlar için en büyük hakaretlerinden biri gâvurluk ile itham edilmektir. Söğüt'e beş cavlak gelir. Bunların içinden Âdem Ejderhası bir akşam subaşında Aslıhan'1 görünce ona sarkıntılık eder. Bu arada Kerimcan da olay yerine gelmiştir.

Âdem ejderhası, delikanlıyı baştan savma süzdü. Sol omuzuna karmakarışık yüklendiği silâhlarla molla kılıklı bir hamala benzetti. Adamdan saymadığını iyice belli eden kasıntılı bir sesle konuştu:

- Gâvur mu kız? Gâvur cariyesi mi?

-Karıştırma, gâvuru Müslümanı... Dileğin nedir?

- Kızma Çelebi! Kızgınlara zararım dokunur benim... Gâvur cariyesi olmayınca... Akşamın bu vakti su başında işi ne? 
Aslıhan kendisine "Gâvur cariye" denildiğini duyunca kudurmuş, Kerim'e de güvendiğinden, bakracı var gücüyle sallayıp çekmeğe başlamıştı (Tahir, 2004: 118).

Sögüt topluluğunda Müslümanlar diğer din mensupları arasında ayrı bir yere sahiptir. Müslüman olmuş biri, Hristiyanlara teslim edilmemektedir. Buna en güzel örnek Mavro'nun durumudur. Karacahisar tekfuru, yanında Alışar Bey'in de olduğu bir grupla Nurettin Bey’in sarayındaki Osman Bey ve adamlarına baskın yapmak niyetindedir. Bununla birlikte Mavro’yu bahane ederler. Mavro'nun Hristiyan olan ablasının ölümünde parmağı olduğunu ileri sürerek onu Osman Bey’den isterler. Osman Bey’in bu isteğe yanıtı şu olur: “- Höst! Sözün gerisini dinlemeden... Adam olmadın gitti sefil Alışar... İnkâr eden yok... Mavro Mavro'luktan çıktı çoktaaan... Müslüman oldu Mavro... adı Abdullah oğlu Yavru'dur, iki cumadan beri. Tanrıma şükür...” (Tahir, 2004: 349).

Mavro'nun Müslüman olduğuna dair bilgi Alışar Bey'in yanındaki Hristiyanları etkiler: "Herifler bu lafi duyunca, kendilerini tutamayıp yekinip bineklerini tepiklemiş olacaklar ki, hayvanlar birbirine girdi. Gem kasıp geri basarak zorla diziye geldiler" (Tahir, 2004: 349). Bunun üzerine Alışar Bey, Nurettin Bey'in devreye girmesini ister, Nurettin Bey'in cevabı da aynı yoldadır: Müslüman biri kâfire verilmez: “- Serhoş musun Alışar Bey, sakın kulağın mı duymazlandı? Burası Rimpapa divanı mı, Müslüman tutulup kâfire verilsin? Sen sana gel, ferman kovalamak öyle değil!" (Tahir, 2004: 349).

Mavro bir süreliğine ortadan kaybolmuştur. Orhan Bey, Kerimcan ve Bayhoca, Mavro'nun nerede olduğunu merak etmektedirler. Bayhoca, bey nöbetini "gâvuroğlundan” gece yarısı aldığını, yatağına hiç girmemiş olmasının tuhaf olduğunu söyler. Orhan Bey, Müslüman birine gâvur denmemesini ister. Buna Bayhoca'nın karşılı̆̆ ilginçtir:

Vay vay!... Ben dededen Müslümanım, daha ele geçiremedim gerçek Müslümanlığı... Dünün gâvuru... Direğini bilmez, şartını bilmez İslâmın! Ne kolay!... Bunca yılın dervişiyken Daskalos gâvurluğu atabildi mi bakalım, sırtından şuncacık... Kel Derviş’in yedeklediği herife Müslüman, dedin mi... (Tahir, 2004: 378).

Burada toplumun bir kısmının yeni Müslüman olanları benimsemekte güçlük çektiği, onların Müslümanlığına şüpheyle baktığı görülmektedir. Bununla birlikte bunun toplumun tamamı tarafından benimsenmediğinin de altı çizilmektedir. Osman Bey'in oğlu Orhan Bey'in Bayhoca'nın düşüncesine katılmadığı, Müslüman olmuş birine "gâvur” denilmesini kabul etmediği de vurgulanmaktadır. 


\section{Sonuç}

Devlet Ana romanında din açısından bireylerin ikilik yaşadığı görülür. Farklı kültürlerin bir arada bulunduğu Anadolu coğrafyasında yurt edinmeye, devlet kurmaya çalışan insanların yaşamında bu ikiliğin varlığı olağandır. Türklerin devlet kurma, yeni bir toplum oluşturma sürecinin anlatıldığı Devlet Ana romanında öncelikle İslamiyet öncesi ve İslami inanç kalıpları bireylerin günlük yaşamında kendilerine yer bulur. Bunun yanında Hristiyanlıktan Müslümanlığa geçen bireylerin de eski dinlerine ait kimi davranış kalıplarını yeni dinlerini yaşarken de kullandıkları görülür. Aynı zamanda kimi roman kişileri, bir arada bulundukları kişiler ve farklı kültürel etkilerin yönlendirmesi ile İslam dışı davranışları da sergiler.

Kemal Tahir'in Devlet Ana romanında toplumun içinde bulunduğu yozlaşmayı din adamları etrafında somutlaştırdığı görülür. Din adamları öncelikle dünya malına karşı zayıflıkları ile ön plana çıkarılır. Dervişler ağızlarından "bir lokma bir hırka" ifadesini eksik etmemelerinin yanında savaş sonu ganimet taksiminde en önde yer alanlar olarak zikredilir. Derviş unvanını almış kişiler başka bölgelerden afyon getirir, ırz düşmanları için sıcaklık muskaları yapar. Bunlar dört dine ait hükümleri kendi çıkarları doğrultusunda kullanırken diğer Müslümanların inançlarını sorgulama cesaretini de gösterir.

Toplum tarafindan istenmeyen davranışları nedeniyle insanlar arasında bir ürküntü kaynağı olarak değerlendirilen din adamları kendilerinden biriyle genç kızların evlenmek istemediği, yakınları tarafından miskinlik ile itham edildiği insanlar olarak sergilenir. Kadılar, toplumda adaleti sağlayacakken adaletsizliğin en önemli sorumluları olarak ifade edilir. Bunlar avuçları içine aldıkları dürüst Türk beylerini kendi ahlaksızlıklarına ortak eder. Bu kadılar her türlü ahlaki düşüklüğü sergilerken halkı da maddi anlamda sıkıştırır.

Yazar, din adamlarının sadece Müslüman olanlarını değil Hristiyan olanlarını da ahlaki düşüklük içinde sergiler. Keşişler, bulundukları mağaralarda kendilerini Allah'a yönelmiş göstermelerinin yanında insanları birbirlerine düşürmek için para karşılığında casusluk yapar, çocuklara sarkıntılıkta bulunur. Romanda Müslümanların Hristiyanları hatta yeni Müslümanları kabullenmekte güçlük yaşadıkları kimi roman kişileri aracılığı ile ifade edilir. Müslüman olmuş birinin Hristiyanlara iade edilmesinin kabul edilemez bir davranış olduğunun altı çizilir.

Devlet Ana romanı Osmanlı Devleti'nin kuruluşu sırasında toplumun içinde bulunduğu kaotik durumun genel görünümünü verir. Kemal Tahir, bu kaotik durumun en önemli amilinin dinî kendi çıkarları doğrultusunda kullanan insanlar olduğunun altını çizer. Böylece Kemal Tahir, dinin toplum için dikkat edilmesi gereken bir olgu olduğunu vurgulamış olur. Bunun 
yanında Kemal Tahir, oluşum sürecini anlattığı Osmanlı Devleti'nin kültürel altyapısının farklı inanç sistemlerinin bir araya gelmesiyle meydana geldiğini gösterir.

\section{Kaynaklar}

ATAR, F. (2001). Kadı. İslâm Ansiklopedisi. İstanbul: Türkiye Diyanet Vakfı Yayınları, 24, 6669.

BEYDİLI, C. (2005). Türk Mitolojisi Ansiklopedik Sözlük. Ankara: Yurt Yayınları.

COŞKUN, S. (2006). Kemal Tahir - Şahsiyeti, Eserleri, Fikirleri. Yayımlanmamış Doktora Tezi, İstanbul: Marmara Üniversitesi Türkiyat Araştırmaları Enstitüsü.

ÇORUHLU, Y. (1999). Türk Mitolojisinin ABC'si. İstanbul: Kabalcı Yayınları.

ÇORUHLU, Y.(2011). Türk Mitolojisinin Ana Hatları. (4. Baskı). İstanbul: Kabalcı Yayınları.

GÜNDÜZ, Ş. (2002). Keşiş. İslâm Ansiklopedisi, İstanbul: Türkiye Diyanet Vakfı Yayınları, $25,322-324$.

GÜNDÜZ, O. (2011). Cumhuriyet Dönemi Türk Romanı. Yeni Türk Edebiyatı El Kitabı 18392000. (6. Bask1). Ankara: Grafiker Yayınları, 399-544.

ENGINÜN, İ. (2012). Yeni Türk Edebiyatı Araştırmaları 2. İstanbul: Dergâh Yayınları.

KABAKLI, A. (2004). Türk Edebiyatı. İstanbul: Türk edebiyatı Vakfı Yayınları.

KERMAN, Z. (2009). Yeni Türk Edebiyatı İncelemeleri. (2. Bask1). İstanbul: Dergâh Yayınları.

KOLCU, A. İ. (2013). Türk Romanı El Kitabı. Erzurum: Salkımsöğüt Yayınları.

KUDRET, C. (1990). Türk Edebiyatında Hikâye ve Roman 3. İstanbul: İnkılap Kitabevi.

POSPELOV, G.(2005). Edebiyat Bilimi. (Çev. Yılmaz ONAY). (2. Baskı). İstanbul: Evrensel yayınları.

ROUX, J. P.(1994). Türklerin ve Moğolların Eski Dini. (Çev. Aykut KAZANCIGİL). İstanbul: İşaret Yayınları.

ROUX, J. P. (2011). Eski Türk Mitolojisi. (Çev. Musa YAŞAR SAĞLAM). Ankara: Bilgesu Yayınları.

TAHIR, K. (2004). Devlet Ana. (18. bask1). İstanbul: Tekin Yayınları.

TOPALOĞLU, B. ( 1995). Esmâ-i Hüsnâ. İslâm Ansiklopedisi, İstanbul: Türkiye Diyanet Vakfı Yayınları, 11, 404-418.

YALÇIN, A.(1992). Cumhuriyet Dönemi Türk Romanı. (2. Baskı). Ankara: Güneş Yayınları.

YAVUZ, N. (2000). Kemal Tahir'in Siyasal ve Toplumsal Görüşleri. Yayımlanmamış Doktora Tezi, Ankara: Ankara Üniversitesi Sosyal Bilimler Enstitüsü.

YAZICI, T. (1994). Derviş. İslam Ansiklopedisi, İstanbul: Türkiye Diyanet Vakfı Yayınları, 9, 188-190. 